Original Research Paper

\title{
Phytochemical test of several eco-handsanitizer candidates
}

\author{
Ratna Dewi Eskundari ${ }^{1 *}$, Tri Wiharti ${ }^{1}$, Nur Rokhimah Hanik ${ }^{1}$, Fety Fatimah ${ }^{1}$, Umi \\ Salamah $^{1}$, Antik Murwani ${ }^{1}$ \\ ${ }^{1}$ Program Studi Pendidikan Biologi, Fakultas Keguruan dan Ilmu Pendidikan, Universitas Veteran \\ Bangun Nusantara, Sukoharjo, Indonesia
}

\author{
Article History \\ Received : December $15^{\text {th }}, 2021$ \\ Revised : December 30 ${ }^{\text {th }}, 2021$ \\ Accepted : January $20^{\text {th }}, 2022$ \\ Published : January $28^{\text {th }}, 2022$ \\ *Corresponding Author: \\ Ratna Dewi Eskundari, \\ Universitas Veteran Bangun \\ Nusantara, Sukoharjo, \\ Indonesia; \\ Email: \\ ratnaeskundari87@gmail.com
}

\begin{abstract}
Ecoenzymes are natural ingredients formed from the fermentation of fruit and or vegetable residues that have many benefits. One of the benefits of ecoenzymes is that they can be used as eco-handsanitizers; which can be used as a candidate for handsanitizer for those who are allergic to alcoholbased handsanitizer. This study aims to determine the $\mathrm{pH}$, antibacterial, antiviral, and antifungal content of the candidate eco-handsanitizer solution through alkaloid, flavonoid, and saponin test, also fungal-inhibition test. The candidate eco-handsanitizer solution was made from an ecoenzyme solution derived from fruit or vegetable residue and added with aloe vera gel and vitamin $\mathrm{C}$ or $\mathrm{E}$. The results showed that eco-handsanitizer candidate solution derived from ecoenzyme solution with a dilution of 1:500 or 1:4 and added with aloe vera and vitamin $\mathrm{E}$ had a $\mathrm{pH}$ that tends to be acidic after 5 weeks of manufacture. The candidate eco-handsanitizer solution contained alkaloid compounds up to $2^{\text {nd }}$ week for 1:500 dilution or up to $5^{\text {th }}$ week for 1:4. Fungal test also showed positive results of one of the treatments in inhibiting fungal growth until the 11th day. These results were expected to be used as guidelines for further research, such as quantitative and qualitative tests for more sensitive alkaloids, for example using GC-MS.
\end{abstract}

Keywords: eco-enzyme; eco-handsanitizer, phytochemical test.

\section{Pendahuluan}

Akhir-akhir ini masih menjadi tren bahwa organik dirasa lebih baik daripada kimiawi. Adanya fenomena back to nature dan organik membuat pengusaha berlomba untuk mendapatkan pangsa pasar yang sekarang ini makin bertambah (Mirza et al. 2017). Selain itu, memang ditinjau dari segi kesehatan maupun keamanan lingkungan, terbukti bahwa produk organik lebih baik dibandingkan produk yang berasal dari kimiawi, selain juga terkait dengan peningkatan perekonomian masyarakat (Sampurno, 2007). Masa pandemi Covid-19 yang sudah berlangsung sekitar 2 tahun ini telah membuat hampir seluruh warga dunia lebih memperhatikan kesehatan. Salah satu langkah pokok yang harus dilakukan oleh semua warga khususnya di Indonesia, dikenal dengan istilah 5 M yaitu memakai masker, menjaga jarak, mencuci tangan, menghindari kerumunan, dan mengurangi mobilitas (Aulia et al. 2021; Irwan et al. 2021; Lestari \& Wicaksono. 2021; Saiful \&
Abhipraya, 2021). Lebih jauh, pada aspek mencuci tangan, memang lebih dianjurkan mencuci tangan dengan sabun dan air mengalir, tetapi dalam keadaan terpaksa terdapat pilihan penggunaan handsanitizer. Untuk mengurangi kelemahan handsanitizer berbahan dasar alkohol terkait aspek sensitifitas kulit, biasanya ditambahkan dengan bahan pelembut tangan misalnya lidah buaya atau gliserin. Lidah buaya dipercaya dapat mengurangi kekeringan kulit karena kemampuannya dalam menghidrasi kulit (Ariani \&Suharsanti, 2018; Aryani 2019). Selain manfaatnya dalam menghidrasi kulit, lidah buaya juga mempunyai manfaat seperti antibakteri (Tampubolon, 2020); Putri \& Milanda (2016); Ariyanti et al., 2012) dan antijamur (Afifah \& Nurwaini (2019)). Dengan demikian, secara ilmiah lidah buaya dapat digunakan untuk bahan tambahan pembuatan handsanitizer.

Ekoenzim yang merupakan salah satu produk bioteknologi sederhana, saat ini menjadi booming karena bertambahnya kesadaran masyarakat pada keunggulan produk organik. 
Karena ekoenzim dibuat dari fermentasi sisa buah dan sayur dengan gula aren atau molase selama sekitar 3 bulan (Megah et al. 2018) maka diharapkan "bakteri baik" yang menempel pada kulit buah atau sayur dapat mengakibatkan adanya atau menambah manfaat dari hasil fermentasi tersebut sehingga diperoleh ekoenzim. Bagian supernatan dari proses fermentasi ekoenzim dilaporkan dapat bermanfaat untuk pupuk cair organik, bahan pencuci, maupun antiseptik (Astuti et al. 2020; Chandra et al. 2020; Sari et al. 2020; Surtikanti et al. 2021). Aspek sebagai antiseptik inilah yang selanjutnya dapat dijadikan dasar pembuatan handsanitizer yang bersifat organik.

Handsanitizer organik yang berbahan dasar ekoenzim telah banyak dilaporkan misalnya dengan menggunakan supernatan dari ekoenzim yang telah diencerkan 1:500 (Chandra et al. 2020). Daya hambat handsanitizer ini dilaporkan mempunyai bahan aktif berupa alkaloid dan tanin yang mempunyai kemampuan sebagai antibakteri, antijamur, dan antivirus, sehingga dapat diarahkan ke penggunaan berupa handsanitizer (Ariningrum et al. 2020; Rahayu et al. 2021). Walaupun telah ada beberapa penelitian tentang handsanitizer berbahan dasar ekoenzim seperti yang telah disebutkan tadi, tapi sampai sekarang belum pernah dilaporkan handsanitizer berbahan dasar ekoenzim yang ditambahkan dengan lidah buaya. Dengan demikian, hal inilah yang mendorong peneliti untuk mengetahui informasi ilmiah handsanitizer berbahan dasar ekoenzim dengan tambahan lidah buaya.

\section{Bahan dan Metode}

\section{Pembuatan handsanitizer yang berbahan dasar ekoenzim}

Tahap ini diawali dengan pembuatan ekoenzim dengan fermentasi sisa sayur (batang brokoli, wortel dan, kecambah) serta sisa buah (kulit nanas dan kulit jeruk) serta molase dalam kurun waktu 3 bulan. Penyaringan dilakukan sehingga didapatkan larutan ekoenzim yang jernih. Larutan ekoenzim selanjutnya diencerkan dengan kadar $0.02 \mathrm{v} / \mathrm{v}$ dan dibuat beberapa perlakuan yaitu :

a. Larutan ekoenzim berbahan sayur b. Larutan ekoenzim berbahan sayur + vitamin C

c. Larutan ekoenzim berbahan sayur + vitamin $\mathrm{E}$

d. Larutan ekoenzim berbahan buah

e. Larutan ekoenzim berbahan buah + vitamin $\mathrm{C}$

f. Larutan ekoenzim berbahan buah + vitamin $\mathrm{E}$

Masing-masing perlakuan tersebut ditambahkan dengan lidah buaya sebanyak 1/4 volume total. Khusus untuk perlakuan yang ditambahkan dengan vit $\mathrm{C}$ dan vit $\mathrm{E}$, dosis vitamin $\mathrm{C}$ dan vitamin $\mathrm{E}$ yang ditambahkan dalam larutan masing-masing sebesar $500 \mathrm{mg}$ dan 300 IU pada setiap $60 \mathrm{~mL}$ cairan lidah buaya.

\section{Pengukuran derajat keasaman (pH)}

Semua sampel diukur $\mathrm{pH}$ nya menggunakan kertas $\mathrm{pH}$ (Merck) pada waktu penyimpanan $0,7,21$ hari setelah pembuatan (HSP).

\section{Uji fitokimia}

\section{a. Uji alkaloid}

Sebanyak $2 \mathrm{~mL}$ larutan ekoenzim ditambahkan dengan $\mathrm{H}_{2} \mathrm{SO}_{4} 2 \mathrm{~N}$ dan diuji dengan pereaksi Wagner. Pereaksi Wagner dibuat dengan melarutkan iodin $2.5 \mathrm{~mL}$ dengan $10 \mathrm{~mL}$ dan diencerkan hingga 200mL. Uji positif ditunjukkan dengan terbentuknya endapan coklat sampai kuning.

\section{b. Uji Flavonoid}

Sebanyak $2 \mathrm{~mL}$ sampel dipanaskan hingga mendidih selama 5 menit. Selanjutnya sampel tersebut ditambahkan sedikit serbuk $\mathrm{Mg}$ dan $1 \mathrm{~mL} \mathrm{HCl}$ lalu dikocok kuat. Uji positif ditunjukkan dengan terbentuknya warna merah, kuning, atau jingga (Sutisna, 2000).

\section{c. Uji saponin}

Sebanyak $2 \mathrm{~mL}$ sampel ditambahkan air panas sebanyak 10 tetes dan ditetesi dengan HCl. Uji positif ditunjukkan dengan 
terbentuknya busa permanen sekitar 15 menit (Darwis, 2000).

\section{Uji jamur}

Pengujian ini dilakukan menggunakan roti tawar. Tangan yang telah disemprotkan larutan handsanitizer ditempelkan di roti tawar dan diamati ada tidaknya pertumbuhan jamur. Sebagai kontrol positif yaitu tangan yang tidak disemprotkan larutan handsanitizer, sedangkan kontrol negatif yaitu tangan yang disemprotkan larutan handsanitizer komersial (merk: Sanex).

\section{Hasil dan Pembahasan}

\section{pH}

Larutan ekoenzim yang digunakan dalam penelitian ini dibuat dari sisa tiga jenis sayur dan dua jenis buah. Keduanya difermentasi menggunakan gula aren sehingga berwarna lebih terang dibandingkan yang difermentasi menggunakan molase. Hal ini dikarenakan adanya perbedaan komposisi gula pada keduanya yaitu komposisi kimia utama gula aren adalah karbohidrat, protein, lemak, dan air (Setiawan, 2020) sedangkan komposisi utama molase adalah karbohidrat, asam amino, dan mineral (Rochani et al. 2015).

Pengukuran $\mathrm{pH}$ saat awal pembuatan ecohandsanitizer ternyata berbeda dengan $\mathrm{pH}$ setelah 11 minggu pembuatan yaitu perubahan $\mathrm{pH}$ mengarah ke $\mathrm{pH}$ asam. Dari Gambar 1 dapat dikatakan bahwa larutan kandidat ecohandsanitizer yang ditambahkan vit $\mathrm{C}$ berpH asam, sedangkan yang ditambahkan dengan vit $\mathrm{E}$ ataupun hanya berupa larutan ekoenzim bersifat asam mendekati netral. Hal ini kemungkinan efek dari pengenceran larutan ekoenzim dengan air dengan perbandingan 1:500, sehingga menyebabkan $\mathrm{pH}$ larutan kandidat ecohandsanitizer cenderung normal (kecuali yang ditambah dengan vitamin $\mathrm{C}$ ), walaupun biasanya $\mathrm{pH}$ larutan ekoenzim tanpa pengenceran bersifat asam (Etienne, 2013; Rochyani et al. 2020) dengan adanya kandungan asam asetat; yang dikenal sebagai anti bakteri, antivirus, dan antijamur (Rochyani et al. 2020). Perubahan $\mathrm{pH}$ ternyata terjadi setelah 11 minggu dari awal pembuatan larutan kandidat eco-handsanitizer yaitu hampir keseluruhan larutan kandidat ecohandsanitizer mempunyai $\mathrm{pH}$ cenderung asam yakni berkisar 4-5, kecuali larutan kandidat eco- handsanitizer yang berbahan dasar larutan ekoenzim asal sayur yang ditambah dengan vitamin E (Gambar 2). Hal ini kemungkinan diakibatkan adanya proses kimia yang terjadi selama larutan ekoenzim diencerkan dan ditambah dengan ekstrak lidah buaya dan atau vitamin.

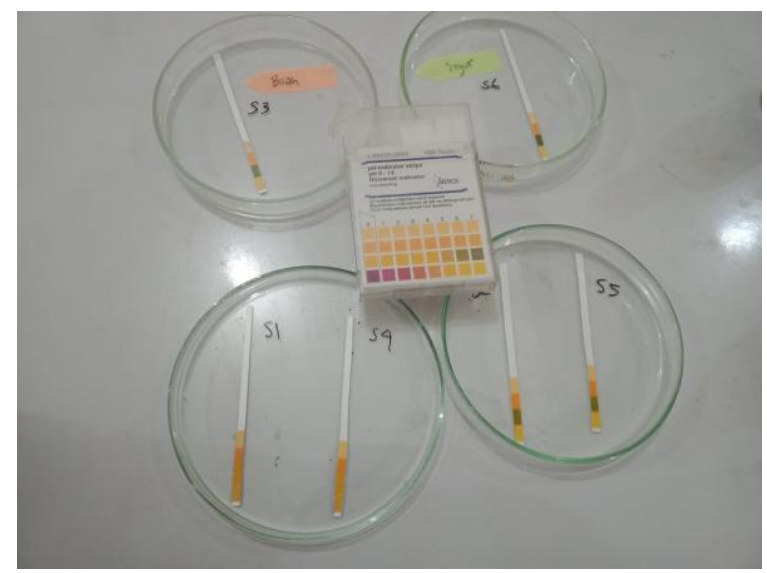

Gambar 1. $\mathrm{pH}$ awal beberapa larutan handsanitizer. $\mathrm{S} 1$ : larutan ekoenzim sisa buah + vit $\mathrm{C}$; S2: larutan ekoenzim sisa buah + vit E; S3: larutan ekoenzim sisa buah; S4: larutan ekoenzim sisa sayur + vit C; S5: larutan ekoenzim sisa sayur + vit E; S6: larutan ekoenzim sisa sayur.

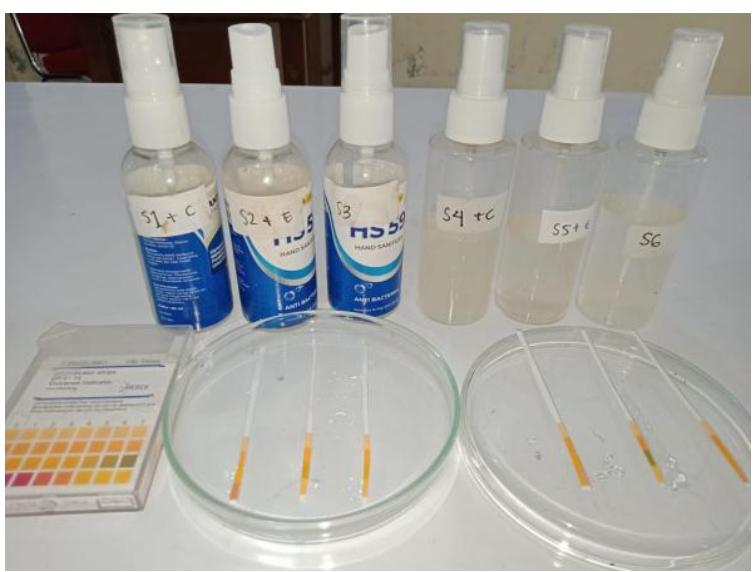

Gambar 2. pH yang diukur setelah 11 minggu pembuatan beberapa larutan handsanitizer. S1: larutan ekoenzim sisa buah + vit C; S2: larutan ekoenzim sisa buah + vit E; S3: larutan ekoenzim sisa buah; S4: larutan ekoenzim sisa sayur + vit C; S5: larutan ekoenzim sisa sayur + vit E; S6: larutan ekoenzim sisa sayur.

\section{Uji Fitokimia}

Uji fotokimia yang dilakukan terhadap larutan kandidat eco-handsanitizer adalah uji alkaloid, uji flavonoid, dan uji saponin. Pada minggu pertama setelah pembuatan larutan 
kandidat eco-handsanitizer, hanya uji alkaloid saja yang menunjukkan hasil positif, dan uji ini masih menunjukkan nilai positif untuk salah satu larutan kandidat eco-handsanitizer setelah 2 minggu pembuatan. Selain itu, juga dibuat larutan kandidat eco-handsanitizer dengan pengenceran $25 \%$ larutan ekoenzim dan setelah minggu kelima pembuatannya masih terdapat kandungan alkaloidnya.

\section{a. Uji Alkaloid}

Uji alkaloid pada semua perlakuan maupun kontrol pada minggu pertama menunjukkan hasil yang positif yang ditandai dengan adanya endapan coklat kemerahan pada dasar tabung (Gambar 3). Uji ini diteruskan pada semua perlakuan dan kontrol pada masa simpan 2 minggu tapi hasil positif uji ini hanya terlihat pada perlakuan yang mendapat tambahan vitamin E beserta kontrol (Gambar tidak ditampilkan). Pada minggu ke-5 penyimpanan, dilakukan uji alkaloid lagi dan ternyata semua perlakuan tidak menunjukkan hasil positif alkaloid kecuali kontrol (Gambar 4). Dengan demikian dapat dikatakan bahwa daya simpan larutan kandidat eco-handsanitizer yang dibuat dari larutan ekoenzim dengan pengenceran 1:500 hanya dapat bertahan selama 2 minggu, dengan catatan harus ditambahkan dengan vitamin $\mathrm{E}$ sebesar 300 IU.

Untuk menambah informasi, maka selanjutnya dilakukan uji alkaloid terhadap perlakuan yang dibuat dari pengenceran larutan ekoenzim sebesar $25 \%$, dengan penambahan vitamin $\mathrm{C}$ dan vitamin E. Hasil daya simpan pada minggu pertama hingga minggu ke-5 menunjukkan bahwa sampel yang dibuat dari larutan ekoenzim asal sayur dan ditambahkan dengan vitamin $\mathrm{E}$ masih tetap menunjukkan hasil positif alkaloid (Gambar 5). Hal ini disimpulkan dari adanya pengamatan adanya gumpalan kecoklatan pada dasar tabung reaksi yag diisi dengan sampel tersebut dan direaksikan dengan pereaksi Wegner. Dengan demikian, dapat dapat dikatakan bahwa sementara larutan kandidat ecohandsanitizer dapat dibuat dan terbukti mempunyai kandungan alkaloid pada sampai larutan ekoenzim yang diencerkan $25 \%$ dan ditambahkan dengan vitamin $\mathrm{E}$.

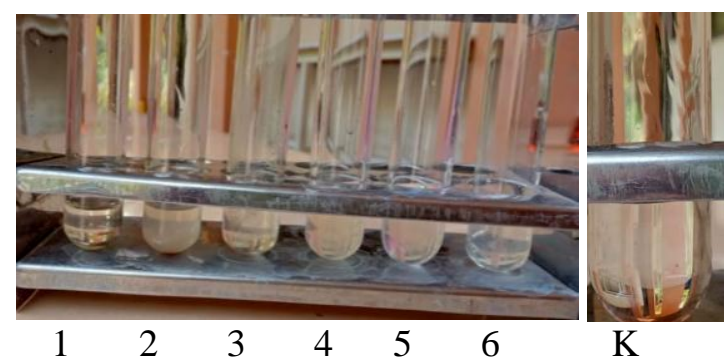

Gambar 3. Uji alkaloid setelah satu minggu pembuatan eco-handsanitizer. 1: larutan ekoenzim sisa buah + vit $C ; 2$ : larutan ekoenzim sisa buah + vit E; 3: larutan ekoenzim sisa buah; 4: larutan ekoenzim sisa sayur + vit C; 5: larutan ekoenzim sisa sayur + vit E; 6: larutan ekoenzim sisa sayur; K : kontrol (merk : Sanex).

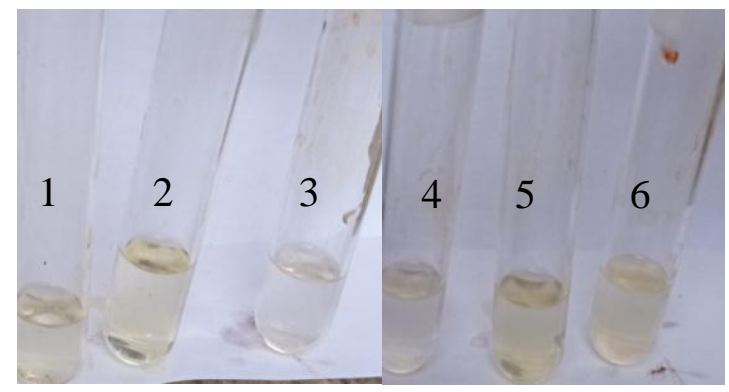

Gambar 4. Uji alkaloid setelah lima minggu pembuatan eco-handsanitizer. 1: larutan ekoenzim sisa buah + vit C; 2 : larutan ekoenzim sisa buah + vit E; 3: larutan ekoenzim sisa buah; 4: larutan ekoenzim sisa sayur + vit C; 5: larutan ekoenzim sisa sayur + vit E; 6: larutan ekoenzim sisa sayur; $\mathrm{K}$ : kontrol (merk : Sanex).

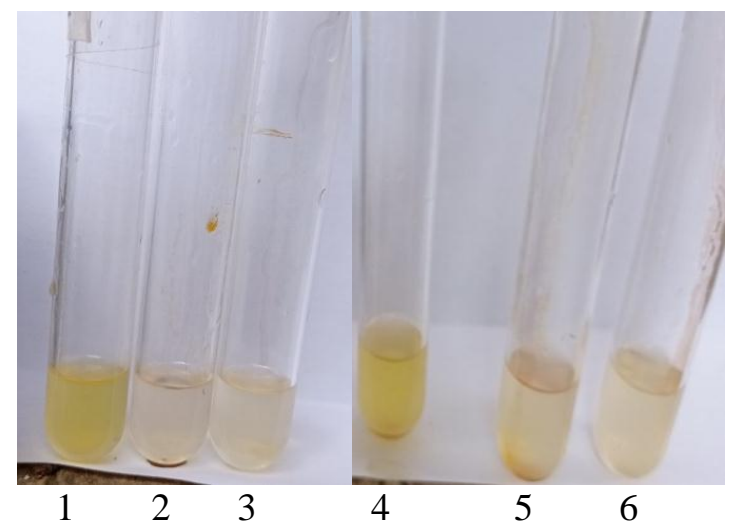

Gambar 5. Uji alkaloid setelah lima minggu pembuatan eco-handsanitizer dengan pengenceran 1:4. 1: larutan ekoenzim sisa buah + vit $\mathrm{C} ; 2$ : larutan ekoenzim sisa buah + vit E; 3: larutan ekoenzim sisa buah; 4: larutan ekoenzim sisa sayur + vit C; 5 : larutan ekoenzim sisa sayur + vit E; 6: larutan ekoenzim sisa sayur. 


\section{b. Uji flavonoid dan saponin}

Larutan kandidat eco-handsanitizer yang telah berumur satu minggu simpan selanjutnya dicek kadar flavonoidnya. Semua perlakuan beserta kontrol tidak menunjukkan adanya flavonoid (Gambar 6). Dengan demikian berarti bahwa pada larutan handsanitizer kontrol maupun semua perlakuan larutan kandidat ecohandsanitizer tidak terkandung metabolit sekunder berupa flavonoid sebagai desinfektannya. Selaras dengan uji flavonoid, sampel beserta kontrol ternyata juga tidak menunjukkan positif uji saponin setelah satu minggu pembuatan ecohandsanitizer. Hal ini dapat ditunjukkan dengan warna semua larutan handsanitizer yang diuji masih tetap berwarna jernih, tidak ada gelembung yang terdapat pada tabung reaksi yang mengarahkan ke uji positif saponin (Gambar 7). Dengan demikian dapat dikatakan bahwa pada semua jenis handsanitizer yang digunakan pada penelitian ini tidak mengandung saponin; salah satu bahan yang dikenal sebagai antimikroba.

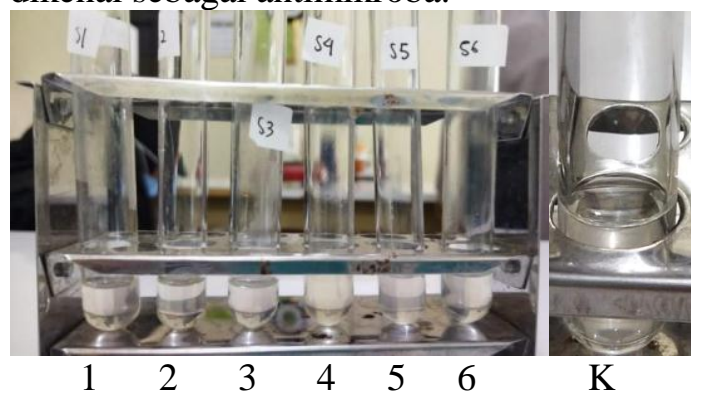

Gambar 6. Uji flavonoid setelah satu minggu pembuatan eco-handsanitizer. 1: larutan ekoenzim sisa buah + vit C; 2 : larutan ekoenzim sisa buah + vit E; 3: larutan ekoenzim sisa buah; 4: larutan ekoenzim sisa sayur + vit C; 5: larutan ekoenzim sisa sayur + vit E; 6: larutan ekoenzim sisa sayur; K : kontrol (merk : Sanex).

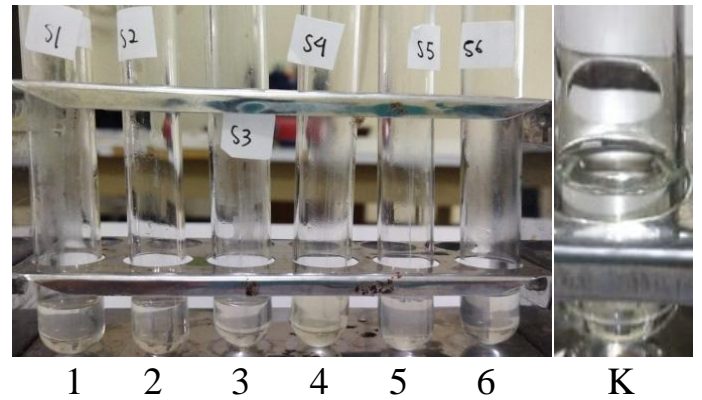

Gambar 7. Uji saponin setelah satu minggu pembuatan eco-handsanitizer. 1: larutan ekoenzim sisa buah + vit C; 2 : larutan ekoenzim sisa buah + vit E; 3: larutan ekoenzim sisa buah; 4: larutan ekoenzim sisa sayur + vit C; 5: larutan ekoenzim sisa sayur + vit E; 6: larutan ekoenzim sisa sayur; $\mathrm{K}$ : kontrol (merk : Sanex).

\section{c. Uji Jamur}

Pengujian daya hambat larutan kandidat eco-handsanitizer terhadap pertumbuhan jamur dilakukan dengan cara sederhana yaitu menggunakan roti tawar. Hasil uji jamur menunjukkan bahwa salah satu larutan kandidat eco-handsanitizer yaitu yang berasal dari buah dan ditambahkan dengan vitamin E serta kontrol terbukti dapat menghambat pertumbuhan jamur hingga 11 hari (Gambar 8). Dengan demikian, dapat dikatakan bahwa larutan kandidat ecohandsanitizer yang berbahan dasar buah dengan tambahan vitamin $\mathrm{E}$ mempunyai zat aktif penghambat jamur sampai sekitar minggu ke-2 setelah pembuatan.

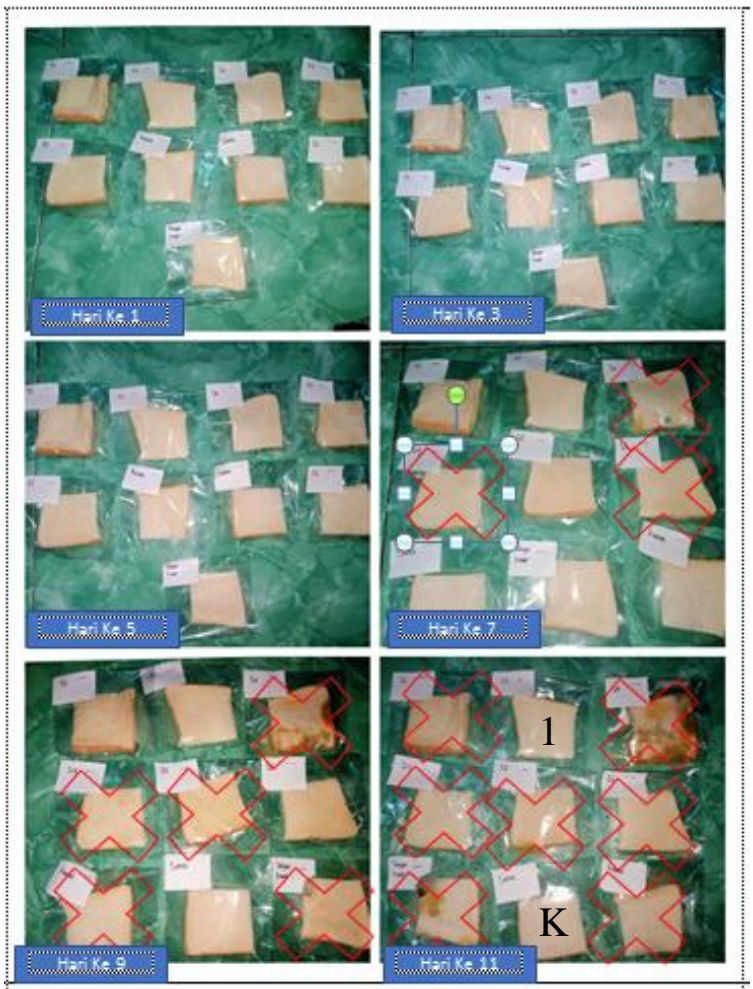

Gambar 8. Uji jamur pada beberapa larutan kandidat eco-handsanitizer. Pada hari ke-11, angka 1: larutan kandidat eco-handsanitizer yang berasal dari buah dan ditambahkan dengan vitamin E; K: kontrol (Sanex).

\section{Kesimpulan}

Larutan kandidat eco-handsanitizer yang berasal dari larutan ekoenzim dengan pengenceran 1:500 atau 1:4 dan ditambahkan 
dengan aloe vera serta vitamin $\mathrm{E}$ mempunyai $\mathrm{pH}$ cenderung asam setelah 5 minggu pembuatan. Selain itu, larutan kandidat eco-handsanitizer juga mempunyai kandungan alkaloid sampai masing-masing minggu ke- 2 dengan pengeceran 1:500 atau sampai minggu ke-5 setelah pembuatan dengan pengenceran 1:4. Larutan kandidat eco-handsanitizer tersebut juga mengandung zat antijamur sampai dengan 2 minggu setelah pembuatan.

\section{Ucapan Terima Kasih}

Penulis mengucapkan terima kasih kepada Rektor dan ketua LPPM Universitas Veteran Bangun Nusantara beserta seluruh jajarannya atas hibah internal penelitian tahun 2021 sehingga penelitian ini dapat terlaksana dengan baik.

\section{Referensi}

Afifah, H., \& Nurwaini, S. (2019). Uji aktivitas antijamur gel serbuk lidah buaya (Aloe vera L.) berbasis Carbopol 934 terhadap Candida albicans dan Trichophyton mentagrophytes. Pharmacon: Jurnal Farmasi Indonesia, 15(2), 42-51. https://doi.org/10.23917/pharmacon.v15i2 .7658

Ariyanti, N. K., Darmayasa, I. B. G., \& Sudirga, S. K. (2012). Daya hambat ekstrak kulit daun lidah buaya (Aloe barbadensis Miller) terhadap pertumbuhan bakteri Staphylococcus aureus ATCC 25923 dan Escherichia coli ATCC 25922. Jurnal Biologi, 16(1), 1-4. https://ojs.unud.ac.id/index.php/BIO/artic le/view/5301

Ariani, L. W., \& Suharsanti, R. (2018). Pelembab alami sediaan shooting gel kombinasi lidah buaya dan buah rambutan. Cedekia Eksakta, http://dx.doi.org/10.3194/ce.v3i1.2144

Ariningrum, N. D., Nurjanah, B. A. D., Maulana, M. R., \& Harismah, K. (2020). Uji efektivitas gel hand sanitizer sebagai antiseptik tangan berbasis ekstrak daun trembesi (Albizia saman (Jacq.) Merr) dan stevia. Prosiding SNPBS (Seminar Nasional Pendidikan Biologi dan Saintek) Ke-5. https://publikasiilmiah.ums.ac.id/bitstrea m/handle/11617/12304/p.506513\%20Nurul\%20Diah.pdf?sequence $=1$

Aryani, R. (2019). Uji efektivitas krim pelembab yang mengandung gel daun lidah buaya (Aloe vera Linn.) dan etil vitamin C. Jurnal Ilmiah Farmasi Farmasyifa, 2(1), 52-61. https://doi.org/10.29313/jiff.v2i1.4203.

Astuti, A. P., \& Maharani, E. T. W. (2020). Pengaruh variasi gula terhadap produksi ekoenzim menggunakan limbah buah dan sayur. Edusaintek, 4: 470-479. https://prosiding.unimus.ac.id/index.php/e dusaintek/article/view/589.

Aulia, G., Fahriati, A. R., Ratnaningtyas, T. O., Utami, S. M., Pratiwi, R. D., Ismaya, N. A., \& Sabrina, P. A. (2021). Edukasi pencegahan Covid-19 dengan protokol kesehatan $5 \mathrm{M}$ dan pentingnya multivitamin di masa pandemi Covid-19. JAM: Jurnal Abdi Masyarakat, 2(1), 133140.

http://openjournal.wdh.ac.id/index.php/J AM/article/view/138

Chandra, Y. N., Hartati, C. D., Wijayanti, G., \& Gunawan, H. G. (2020). Sosialisasi pemanfaatan limbah organik menjadi bahan pembersih rumah tangga. In Prosiding Seminar Nasional Pengabdian Kepada Masyarakat (Vol. 1, pp. SNPPM2020LPK-9). http://journal.unj.ac.id/unj/index.php/snpp m/article/view/19671

Irwan, I., Mopangga, A., \& Mokodompis, Y. (2021). Pengaruh Kepercayaan dan Sikap Terhadap Perilaku 5M (Memakai Masker, Mencuci Tangan, Menjaga Jarak, Menjauhi Kerumunan, Mengurangi Mobilitas) Selama Pandemi Covid19. Journal Health \& Science: Gorontalo Journal Health and Science Community, 5(2), 302-312. https://doi.org/10.35971/gojhes.v5i2.1114 6

Lestari, V. \& Wicaksono, A. P. (2021). Edukasi protokol kesehatan di masa pandemic Covid-19 pada warga Dk. Berdug Kulon RT 01 RW 11 Sidomulyo Ampel Boyolali, Jurnal Ekonomi, Sosial, \& Humaniora, 2(9), 
https://www.jurnalintelektiva.com/index. $\mathrm{php} / \mathrm{jurnal} /$ article/view/458

Megah, S. I., Dewi, D. S., \& Wilany, E. (2018). Pemanfaatan limbah rumah tangga digunakan untuk obat dan kebersihan. MINDA BAHARU, 2(1), 5058.

https://doi.org/10.33373/jmb.v2i1.2275

Mirza, M., Amanah, S., \& Sadono, D. (2017). Tingkat Kedinamisan Kelompok Wanita Tani dalam Mendukung Keberlanjutan Usaha Tanaman Obat Keluarga di Kabupaten Bogor, Jawa Barat. Jurnal Penyuluhan, 13(2), 181-193. https://doi.org/10.22500/13201716090

Puteri, T., \& Milanda, T. (2016). Uji daya hambat ekstrak daun lidah buaya (Aloe vera L.) terhadap Bakteri Escherichia coli dan Staphylococcus aureus. Farmaka, 14(2), 9-17. https://doi.org/10.24198/jf.v14i2.10784

Rochani, A., Yuniningsih, S., \& Ma'sum, Z. (2016). Pengaruh konsentrasi gula larutan molases terhadap kadar etanol pada proses fermentasi. Reka Buana: Jurnal Ilmiah Teknik Sipil dan Teknik Kimia, 1(1), 4348.

https://doi.org/10.33366/rekabuana.v1i1.6 45

Saiful, R., \& Abhipraya, F. A. (2021). Efektivitas pemerintah dalam sosialisasi gerakan $5 \mathrm{M}$ kepada masyarakat. Warta Governare, 2(1). https://www.journal.unwira.ac.id/index.p hp/WG/article/view/1147

Sampurno, 2007. Knowledge-Based Economy : Sumber Keunggulan Daya Saing Bangsa. Penerbit Pustaka pelajar, Cetakan Pertama, Yogyakarta.

Sari, R. P., Astuti, A. P., \& Maharani, E. T. W. (2020). Pengaruh ecoenzym terhadap tingkat keawetan buah anggur merah dan anggur hitam. HIGIENE: Jurnal Kesehatan Lingkungan, 6(2), 70-75. http://journal.uin-

alauddin.ac.id/index.php/higiene/article/vi ew/12239

Setiawan, Y. (2020). Analisis fisikokimia gula aren cair. AGROSCIENCE, 10(1), 69-78. https://doi.org/10.35194/agsci.v10i1.971

Surtikanti, H. K., Kusumawaty, D., Sanjaya, Y., Priyandoko, D., Kurniawan, T., \& Sisri, E. M. (2021). Memasyarakatkan ekoenzim berbahan dasar limbah organik untuk peningkatan kesadaran dalam menjaga lingkungan. Sasambo: Jurnal Abdimas (Journal of Community Service), 3(3), 110-118. https://doi.org/10.36312/sasambo.v3i3.53 2.

Tampubolon, R.M.T. (2020). Efektivitas Ekstrak Lidah Buaya (Aloe vera) terhadap Bakteri Porphyromonas gingivalis secara In Vitro. [Skripsi].Fakultas Kedokteran Gigi, Universitas Sumatra Utara. 